\title{
ВВЕДЕНИЕ В КУЛЬТУРУ IN VITRО И КЛОНАЛЬНОЕ МИКРОРАЗМНОЖЕНИЕ ПЕРСПЕКТИВНОГО СЕЯНЦА СМОРОДИНЫ ЧЕРНОЙ (RUBES NIGRUM L.)
}

\author{
I.S. Kovaleva, A.E. Matsneva, \\ O.E. Khanbabaeva, A.S. Mazaeva

\section{THE INTRODUCTION TO CULTURE IN VITRO AND CLONAL MICROPROPAGATION OF PERSPECTIVE SEEDLING OF BLACK CURRANT (RIBES NIGRUM L.)}

Ковалева И.С. - ст. науч. сотр. лаб. клонального микроразмножения садовых растений Российского государственного аграрного университета - МСХА им. К.А. Тимирязева, г. Москва.

E-mail: irino4ka_koval@mail.ru

Мацнева A.E. - мл. науч. сотр. лаб. клонального микроразмножения садовых растений Российского государственного аграрного университета - МСХА им. К.А. Тимирязева, г. Москва.

E-mail:macnusha@mail.ru

Ханбабаева O.E. - канд. с.-х. наук, доц. каф. ландшафртной архитектуры Российского государственного аграрного университета - MCXА им. К.А. Тимирязева, г. Москва.

E-mail: hanbabaeva@yandex.ru

Мазаева А.C. - асп. каф. плодоводства и виноградарства Российского государственного аграрного университета - МСХА им. К.А. Тимирязева, г. Москва.

E-mail: maeva91@mail.ru

В лаборатории плодоводства РГАУ-МСХА им. К.А. Тимирязева выделен сеянеи смородины черной 137, полученный от свободного опьления и сочетающий в себе оптимальный комплекс хозяйственно ценных признаков: стабильно высокую урожайность, крупноплодность, зимостойкость, устойчивость к мучнистой росе. Для ускорения процесса внедрения ценного генотипа в производство, а также получения здорового растительного материала с высоким потенциалом к дальнейшему вегетативному размножению in vitro разрабатывались основные этапы клонального микроразмножения сеянца смородины. Для инициации культуры использовали апексы, изолированные из покоящихся апикальных и латеральных почек и молодых развивающихся по-
Kovaleva I.S. - Senior Staff Scientist, Lab. of Clonal Garden Plants Microreproduction, Russian State Agrarian University - MAA named after K.A. Timiryazev, Moscow.

E-mail: irino4ka_koval@mail.ru

Matsneva A.E. - Junior Staff Scientist, Lab. of Clonal Garden Plants Microreproduction, Russian State Agrarian University - MAA named after K.A. Timiryazev, Moscow.

E-mail: macnusha@mail.ru

Khanbabaeva O.E. - Cand. Agr. Sci., Assoc. Prof., Chair of Landscape Architecture, Russian State Agrarian University - MAA named after K.A. Timiryazev, Moscow.

E-mail: hanbabaeva@yandex.ru

Mazaeva A.S. - Post-Graduate Student, Chair of Fruit Growing and Wine Growing, Russian State Agrarian University - MAA named after K.A. Timiryazev, Moscow.

E-mail: maeva91@mail.ru

бегов. Стерильные экспланты культивировали на питательной среде. В качестве базовой использовали агаризованную среду на основе минеральных элементов Мурасиге и Скуга (1962 г.) (МС), с удвоенной концентрацией хелата железа. Цитокинин - 6-бензиламинопурин (6-БАП) тестировали в концентрациях 0,6; 0,7;0,8 ме/л в комбинации с индолилмасляной кислотой (ИМК) и без. Культуры инкубировали при интенсивности света 1500-2000 люкс, температуре $22{ }^{\circ} \mathrm{C}$ и 16-часовом фотопориоде. Длительность субкультивирования составляла 5 и 8 недель. Исследования показали, что в качестве инициальных эксплантов можно использовать апексы, выделенные как из покоящихся почек, так и из верхушек развивающихся побегов сеяниа смородины. На ста- 
дии инициации культуры для уменьшения риска возникновения витрификации целесообразно использовать вариант питательной среды МС с 6-БАП (0,7 ме/л) в сочетании с ИМК (0,1 ме/л). На стадии собственно микроразмножения лучшие результаты получены при снижении концентрации 6-БАП до 0,6 мг/л. Для укоренения микропобегов оптимальна среда МС без гормонов. Модификацию питательной среды МС с 6-БАП и ИМК в концентрациях 0,8 и 0,1 ме/л соответственно целесообразно применять для беспересадочного хранения в течение 3-4 месящев. После адаптащии пересадку регенерантов из кассет в пластиковые контейнеры необходимо производить не раньше чем через шесть недель от начала культивирования. B ходе работы изучены этапы клонального микроразмножения сеянца смородины черной: установление стерильной культуры, регенерация из эксплантов различного происхождения, мультиплицирование, укоренение in vitro, адаптация в нестерильных условиях.

Ключевье слова: смородина черная, сеянец, микроразмножение, микропобег, питательная среда, регенерационная способность, adanmauия.

In the Laboratory of Fruit Growing of Russian State Agrarian University-Moscow Timiryazev Agricultural Academy isolated black currant seedling obtained from free pollination and combining optimal complex of economically valuable traits: stably high yield, large-fruit, winter hardiness and resistance to powdery mildew. To accelerate the process of introducing a valuable genotype into production, as well as to obtain healthy plant material with high potential for further vegetative propagation in vivo the main stages of clonal micropropagation of a seedling blackcurrant were developed. To initiate culture the apexes isolated from resting apical and lateral buds and young developing shoots were used. Sterile explants were cultured on nutrition medium. Agarised medium based on mineral elements Murashige and Skoog (1962) (MS), with twice the concentration of iron chelate was used as base medium. Cytokinin 6-benzylaminopurin (6-BAP) was tested at concentrations of $0.6 ; 0.7 ; 0.8 \mathrm{mg} / \mathrm{l}$ in combination with indolylbutyric acid (IBA) and without it. The cultures were incubated at light intensity of 1500-2000 Lux, the temperature of $22{ }^{\circ} \mathrm{C}$ and photoperiod lasting 16 hours. The duration of the subculture was 5 and 8 weeks. The studies showed that apexes isolated from both resting buds and the tops of developing shoots of currant seedling could be used as initial explants. At the stage of culture initiation to reduce the risk of vitrification, it is advisable to use the variant of the MS nutrient medium with 6-BAP $(0.7 \mathrm{mg} / \mathrm{l})$ in combination with IBA $(0.1 \mathrm{mg} / \mathrm{l})$. At the stage of shoot propagation namely, the best results were obtained by reducing the concentration of 6-BAP to $0.6 \mathrm{~m} / \mathrm{l}$. MS nutrient medium without hormones was optimal for rooting microshoots. The modification of the nutrient medium MS with adding 6-BAP and IBA in concentrations of 0.8 and $0.1 \mathrm{mg} / \mathrm{l}$ it to apply for storage without transplant culture for 3-4 months. After the adaptation, the transplant of regenerants from the cassettes into plastic containers should be made not earlier than six weeks after the beginning of cultivation. In the course of work, the stages of clonal micropropagation of the blackcurrant seedling were studied: the establishment of sterile culture, regeneration from explants of various origin, multiplication, rooting in vitro, adaptation in non-sterile conditions.

Keywords: black currant, seedling, clonal micropropagation, microshoot, nutrition medium, regenerative ability, adaptation.

Введение. Смородина черная (Rubes nigrum L.) является популярной и перспективной ягодной культурой в России. Ягоды черной смородины - самый доступный источник витаминов С и P, а также целого комплекса биологически активных веществ: органических кислот, сахаров, эфирных масел. Источниками витаминов служат не только ягоды, но и листья, почки, кора годичных приростов $[1,2]$.

Культура неприхотлива, пластична, хорошо растет на любых влагоемких почвах, начиная с юга нашей страны, заходя в северные регионы.

Учитывая широкую распространенность и важность культуры смородины черной, актуальным является создание новых высокоурожайных сортов с высоким уровнем адаптации к биотическим фракторам. Наряду с селекцией на повышение уровня продуктивности, одной из актуальных задач в селекции смородины черной является создание сортов, устойчивых к наибо- 
лее опасной болезни в нашей зоне - мучнистой poce, а в перспективе - создание сортов с комплексной устойчивостью к болезням и вредителям. Особенно это важно для получения экологически чистой продукции, чтобы исключить или существенно ограничить применение ядохимикатов [2, 3].

Интенсификация селекции связана с привлечением современных биотехнологических приемов, в том числе клонального микроразмножения, позволяющих существенно ускорить селекционный процесс, решить проблему размножения генетически ценного материала, свободного от патогенов и вредителей [4].

В лаборатории плодоводства РГАУ-МСХА им. К.А. Тимирязева в 2010-2011 гг. был выделен сеянец смородины черной 137, полученный от свободного опыления. Испытания данного образца в грунте проводили в течение 7 лет. Сеянец характеризуется следующими качествами: урожайность стабильно высокая, ягоды крупные с высоким содержанием сахара, кисти длинные, долго не осыпается. Куст каскадного типа высотой до 2,5 м, раскидистый. Сеянец устойчив к мучнистой росе. Зимостойкий.

Цель работы. Разработка основных этапов клонального микроразмножения перспективного сеянца смородины черной.

Задачи исследований: ввести в культуру in vitro ценный генотип, подобрать оптимальные условия культивирования на искусственной питательной среде и адаптации пробирочных растений на традиционных субстратах ex vitro, в краткие сроки получить здоровые растения с повышенной способностью к дальнейшему вегетативному размножению вследствие процессов реювенилизации [5].

Материалы и методы. Введение в культуру in vitro проводили в сентябре 2018 г. Одревесневшие черенки сеянца смородины черной были взяты с маточника из открытого грунта, расположенного в Дмитровском районе. В качестве первичных эксплантов были использованы апексы, выделенные из покоящихся апикальных и латеральных почек и молодых развивающихся побегов. Рост побегов стимулировали предварительным черенкованием исходного экземпляра в соответствии с методикой, предложенной ранее для флокса метельчатого [6]. Для этого с маточного экземпляра нарезали черенки длиной 15-20 см с 4-5 почками и помещали их в чистый перлит, чтобы избежать инфицирования патогенной микрофлорой. Обработку черенков ауксином не производили. Через 2-3 недели в стадии активного роста молодых побегов осуществляли отбор эксплантов.

Перед стерилизацией растительный материал промывали проточной водой с добавлением ПАВ для удаления загрязнений. Последующую обработку проводили в ламинарном боксе по схеме: обработка 70\% этанолом в течение 2-3 секунд, затем 2,5\% раствором гипохлорита натрия в течение 8 минут. Затем растительный материал трехкратно промывали стерильной дистиллированной водой. Изоляцию апексов производили при помощи специальных инструментов в стерильных условиях под бинокулярным микроскопом. Стерильные экспланты помещали в пробирки на агаризованную питательную среду. В качестве базовой использовали питательную среду на основе минеральных солей Мурасиге и Скуга (МС) (1962 г.), обогащенную следующими веществами (мг/л): тиамин $\left(\mathrm{B}_{1}\right)$, пиридоксин $\left(\mathrm{B}_{6}\right)$, никотиновая кислота (РP) - по 0,5; инозитол - 100; сахароза - 30000, бакто-агар - 7000 [7]. Концентрацию солей железа увеличивали в 2 раза. В ходе работы использовали 6 вариантов питательной среды МС, различавшихся по концентрации 6-БАП (0,6-0,8 мг/л) и содержанию ИМК (0,1мг/л). На стадии собственно микроразмножения экспланты культивировали в 250 мл пластиковых контейнерах. Культуры инкубировали в световой комнате при интенсивности света 1500-2000 люкс, температуре $22{ }^{\circ} \mathrm{C}$ и 16 -часовом фотопериоде. Снятие данных проводили после 5 и 8 недель культивирования. Учитывали количество дополнительных побегов на эксплант, длину побегов, количество витрифицированных и укорененных растений. Коэффициент размножения рассчитывали из общего числа дополнительных побегов на эксплант и одноузловых сегментов.

Объем варианта по каждой концентрации составлял 30 эксплантов в 3 повторностях. Рассчитывали среднеквадратическое отклонение от средней арифметической.

Результаты и их обсуждение. На этапе введения в культуру использовали 2 модификации питательной среды МС, субкультивирование длилось 5 недель. За это время на инициальных апексах формировались микропобеги в количестве 1-2 шт. на эксплант (табл.1). 
Регенерационная способность апексов сеянца смородины черной in vitro в зависимости от состава питательной среды

\begin{tabular}{|c|c|c|c|c|}
\hline Состав среды, мг/л & $\begin{array}{c}\text { Кол-во жизнеспо- } \\
\text { собных эксплан- } \\
\text { тов, \% }\end{array}$ & $\begin{array}{c}\text { Кол-во витрифрицирован- } \\
\text { ных побегов, \% }\end{array}$ & $\begin{array}{c}\text { Среднее } \\
\text { число по- } \\
\text { бегов на 1 } \\
\text { эксплант }\end{array}$ & $\begin{array}{c}\text { Средний } \\
\text { размер } \\
\text { побегов, } \\
\text { см }\end{array}$ \\
\hline \multicolumn{5}{|c|}{ Апексы из развивающихся побегов } \\
\hline 6-БАП 0,7+ИМК 0,1 & 95 & 10 & $1,4 \pm 0,49$ & $0,8 \pm 0,14$ \\
\hline 6-БАП 0,7 & 90 & 60 & $1,6 \pm 0,49$ & $0,7 \pm 0,12$ \\
\hline \multicolumn{7}{|c|}{ Апексы из покоящихся почек } \\
\hline 6-БАП 0,7+ИМК 0,1 & 80 & 0 & $1,6 \pm 0,49$ & $0,4 \pm 0,10$ \\
\hline 6-БАП 0,7 & 85 & 20 & $1,4 \pm 0,49$ & $0,3 \pm 0,07$ \\
\hline
\end{tabular}

Наблюдения показали, что при стандартной схеме стерилизации различий в степени инфицированности эксплантов, изолированных из покоящихся почек и молодых развивающихся побегов, не было. Приживаемость апексов из побегов была несколько выше (10-15\%), чем приживаемость апексов, выделенных из почек на обоих вариантах питательной среды. Различий в характере развития эксплантов не наблюдали, в обоих случаях побеги развивались быстрее на более крупных эксплантах (3 мм). На среде МС с БАП (0,7 мг/л) без ИМК значительная часть микропобегов витрифицировалась к окончанию субкультивирования. На среде с ауксином витрификацию побегов наблюдали в $10 \%$ случаев.

По окончании субкультивирования микропобеги пересаживали на свежую среду, отбраковывая при этом витрифиццированные экземпляры. На следующем этапе использовали четыре варианта питательной среды (табл. 2).

Таблица 2

\section{Влияние состава питательной среды и длительности субкультивирования на развитие побегов сеянца смородины черной в культуре in vitro}

\begin{tabular}{|c|c|c|c|c|c|c|c|c|}
\hline \multirow{2}{*}{$\begin{array}{c}\text { Содержание } \\
\text { гормонов в } \\
\text { питательной } \\
\text { среде, мг/л }\end{array}$} & $\begin{array}{c}\text { Среднее } \\
\text { число до- } \\
\text { полнитель- } \\
\text { ныхпобегов }\end{array}$ & $\begin{array}{c}\text { Средний } \\
\text { размер } \\
\text { побегов, } \\
\text { см }\end{array}$ & $\begin{array}{c}\text { Кол-во } \\
\text { витрифи- } \\
\text { цирован- } \\
\text { ных побе- } \\
\text { гов, \% }\end{array}$ & $\begin{array}{c}\text { Кол-во } \\
\text { укоре- } \\
\text { нишихся } \\
\text { побегов, } \\
\%\end{array}$ & $\begin{array}{c}\text { Среднее } \\
\text { число } \\
\text { дополни- } \\
\text { тельных } \\
\text { побегов }\end{array}$ & $\begin{array}{c}\text { Средний } \\
\text { размер } \\
\text { побегов, } \\
\text { см }\end{array}$ & $\begin{array}{c}\text { Кол-во } \\
\text { витрифи- } \\
\text { цирован- } \\
\text { ных побе- } \\
\text { гов, } \%\end{array}$ & $\begin{array}{c}\text { Кол-во } \\
\text { укоренив- } \\
\text { шихся по- } \\
\text { бегов, } \%\end{array}$ \\
\hline 6-БАП 0,6 & $2,4 \pm 0,49$ & $0,6 \pm 0,10$ & - & - & $5,0 \pm 0,89$ & $2,4 \pm 0,49$ & - & 10 \\
\hline 6-БАП 0,8 & $7,0 \pm 0,89$ & $0,3 \pm 0,05$ & $10-20$ & - & $11,0 \pm 0,75$ & $0,3 \pm 0,05$ & 100 & - \\
\hline $\begin{array}{c}\text { 6-БАП 0,8+ } \\
\text { ИМК 0,1 }\end{array}$ & $4,2 \pm 0,75$ & $0,7 \pm 0,17$ & - & $5-7$ & $4,2 \pm 0,75$ & $1,4 \pm 0,49$ & - & 80 \\
\hline Без гормонов & $1,6 \pm 0,49$ & $1,2 \pm 0,10$ & - & 30 & $1,6 \pm 0,49$ & $3,0 \pm 0,89$ & - & 100 \\
\hline
\end{tabular}

После 5-недельного культивирования на среде, содержащей 6-БАП в концентрации 0,8 мг/л, наблюдали образование конгломератов, состоящих из 6-8 укороченных микропобегов $(0,2-0,3$ см). По мере увеличения срока культивирования количество дополнительных побегов на эксплант увеличилось до 12. Одно- временно происходила постепенная витрификация культур. К моменту окончания культивирования (через 8 недель) количество витрифицированных конгломератов составило $100 \%$.

Добавление ИМК в концентрации 0,1 мг/л предотвращало образование витрифицированных побегов. Число дополнительных побегов 
составляло 3-5 шт. и не зависело от длительности субкультивирования. После 8 недель культивирования их размер достигал 1-2 см, при этом в 80 \% случаев наблюдали спонтанное образование корней. Укоренение происходило целыми конгломератами, что затрудняло дальнейшее разделение их на отдельные побеги.

Уменьшение витрификации достигалось также снижением концентрации 6-БАП в питательной среде до 0,6 мг/л. В этом случае после 5 недель культивирования формировались конгломераты, состоящие из 2-3 микропобегов размером 0,5-0,8 см. К концу субкультивирования количество побегов на эксплант достигало 4-6 шт., их размер составлял 2-3 см. Разделяя микропобеги на одноузловые сегменты при последующем тиражировании, получали дополнительные субъединицы, таким образом, увеличивали коэффрициент размножения до 6-8 шт. на эксплант. Количество укорененных побегов не превышало $10 \%$.

В связи с тем, что в экспериментах наблюдали спонтанное корнеобразование, микропобеги высаживали на среду без гормонов для направленной индукции ризогенеза. В этом случае количество дополнительных микропобегов на эксплант не зависело от времени культивирования и составляло 1-2 шт. Средний размер побега увеличивался по мере увеличения периода культивирования и составлял 1 и 2-4 см после 5 и 8 недель культивирования соответственно. Укореняемость возрастала от 30 \% после 5 недель выращивания до 100 \% к моменту окончания субкультивирования.

Адаптацию к нестерильным условиям проводили в условиях зимних теплиц в специальных укрытиях. Использовали два вида субстрата: низинный торф и низинный торф с добавлением перлита в соотношении 3:1. Первые две недели после пересадки микрорастения в кассетах содержали под герметичным пленочным укрытием при температуре $22-26{ }^{\circ} \mathrm{C}$, затем постепенно приучали растения к пониженной влажности воздуха. Приживаемость на обоих субстратах составляла 90-95\%. Через три недели после посадки молодые растения вынимали из укрытия. Пересадку из кассет в пластиковые контейнеры проводили в два срока - через три и шесть недель культивирования. В первом случае у растений наблюдали плохую и длительную приживаемость - при сильно развитых по- бегах корневая система была слаборазвита. Такие растения впадали в покой и начинали отрастать только через полтора месяца. Растения, пересаженные из кассет через шесть недель, обладали более развитой корневой системой и впадали в относительно короткий период остановки роста - около двух недель. Через два месяца после посадки еx vitro растения формировали 2-4 побега размером 15-20 см. В отличие от черенкованных растений имели значительную листовую поверхность, большой суммарный прирост, более мощное развитие корневой системы.

Выводы. По итогам проведенных опытов было установлено, что не было существенных различий в степени инфицированности, приживаемости, регенерационной способности инициальных апексов, выделенных их покоящихся почек и развивающихся побегов сеянца смородины.

Содержание ауксина в питательной среде и снижение концентрации 6-БАП значительно уменьшало риск формирования витрифицированных побегов как на стадии инициации, так и на стадии собственно микроразмножения сеянца смородины черной. Питательная среда МС c 6-БАП в концентрации 0,6 мг/л была оптимальной на стадии собственно микроразмножения для данного генотипа. Среда МС с 6-БАП и ИМК в концентрациях 0,8 и 0,1 мг/л также может быть использована, однако необходимо учитывать, что большое количество укорененных растений дает задержку в получении последующих партий растений. Данную модификацию питательной среды целесообразно применять для беспересадочного хранения в течение 3-4 месяцев в межсезонный период. Для укоренения микропобегов рекомендуется использовать среду без гормонов, так как на ней в течение 8 недель микрорастения хорошо развиваются и формируют развитую корневую систему. Для успешного прохождения регенерантами адаптации подращивание в кассетах должно быть не менее шести недель. Растения еx vitro смородины черной отличались от растений, полученных традиционным черенкованием, более интенсивным побегообразованием и скоростью роста.

Полученные экспериментальные данные ускорят процесс дальнейшей передачи ценной формы - перспективного сеянца смородины черной 137 в Государственное сортоиспытание. 


\section{Литература}

1. Куминов Е.П., Жидехина Т.В. Смородина. Харьков: Фолио, 2005. - 256 с.

2. Огольщова Т.П. Селекция черной смородины - прошлое, настоящее, будущее. - Тула: Приок. кн. изд-во, 1992. - 384 с.

3. Князев С.Д., Огольцова Т.П. Селекция черной смородины на современном этапе. Орел: Изд-во ОрелГАУ, 2004. - 237 с.

4. Егорова Т.А., Клунова С.М., Живухина Е.А. Основы биотехнологии: учеб. пособие. - 2-е изд., стереот. - М.: Академия, 2005. - С. 208.

5. Высоцкий В.А. Биотехнологические методы в системе производства оздоровленного посадочного материала и селекции плодовых и ягодных растений: автореф. дис. ... д-ра с.-х. наук. - М., 1998. - С. 44.

6. Ковалева И.С., Мацнева А.Е., Ханбабаева О.Е. [и др.]. Введение в культуру in vitro сеянцев фрлокса метельчатого (Phlox paniculata L.) // Международный научный журнал. - 2017. - № 3. - С. 79-84.

7. Murashige T., Skoog F. A revised medium for rapid growth and bioassays with tobacco tissue cultures // Physiologia Plantarum. 1962. - V. 15. - P. 473-497.

\section{Literatura}

1. Kuminov E.P., Zhidehina T.V. Smorodina. Har'kov: Folio, 2005. - $256 \mathrm{~s}$.

2. Ogol'cova T.P. Selekcija chernoj smorodiny proshloe, nastojashhee, budushhee. - Tula: Priok. kn. izd-vo, 1992. - 384 s.

3. Knjazev S.D., Ogol'cova T.P. Selekcija chernoj smorodiny na sovremennom jetape. - Orel: Izd-vo OrelGAU, 2004. - $237 \mathrm{~s}$.

4. Egorova T.A., Klunova S.M., Zhivuhina E.A. Osnovy biotehnologii: ucheb. posobie. 2-e izd., stereot. - M.: Akademija, 2005. S. 208.

5. Vysockij V.A. Biotehnologicheskie metody $\mathrm{v}$ sisteme proizvodstva ozdorovlennogo posadochnogo materiala i selekcii plodovyh i jagodnyh rastenij: avtoref. dis. ... d-ra s. - h. nauk. - M., 1998. - S. 44.

6. Kovaleva I.S., Macneva A.E., Hanbabaeva O.E. [i dr.]. Vvedenie $v$ kul'turu in vitro sejancev floksa metel'chatogo (Phlox paniculata L.) // Mezhdunarodnyj nauchnyj zhurnal. - 2017. - № 3. - S. 79-84.

7. Murashige T., Skoog F. A revised medium for rapid growth and bioassays with tobacco tissue cultures // Physiologia Plantarum. 1962. - V. 15. - P. 473-497. 